\title{
Dried Spice Technology Improves Effeciency in the Hospitality Industry
}

\author{
Kusumawardhani Yuviani, Sjukriana Juke, Aryanti Ratri \\ Usaha Perjalanan Wisata \\ Sekolah Tinggi Pariwisata Bogor \\ Bogor, Indonesia \\ kusumawardhaniyuvi@gmail.com
}

\begin{abstract}
National food industry has big contribute to the economic growth in Indonesia. In the first quarter of 2015, the growth of the national food industry reached $8.16 \%$. Indonesian traditional food which is famous in the international are rendang, gado-gado, skewers, meatballs, Soto Betawi, and many more. Rendang crowned as the best dish in the world comes from Indonesia. In the cooking process, rendang produce a lot of food waste. Food waste in the few years become an important topic for both major impact on the economy, the environment and food security of a country. Moreover, the impact of food waste also affects the environment that may cause greenhouse emissions, the use of water and land that is not effective and efficient which may cause damage to ecosystems. In addition to the effects provided by food waste, the time needed to make rendang also need quite a long time. The objective this research is to to analyze the efficiency on food production process. It can save more time, have the same taste with dishes that cooked traditionally and produce healthy food. This research use experiment method. The result dried spice are made to cook rendang can save up to 30 minutes when compared to the traditional cooking process. It help someone who working in the food industry especially in the service sector such as hotels, restaurants, and catering. These dried spice, in addition to saving time, taste quality and durability is not doubt. Rendang dried spice can be a solution for those who want a long-lasting healthy food, the taste quality is maintained, and time efficiency in the cooking process.
\end{abstract}

Keywords- Food industry, Dried Spice, Gastronomy, Traditional Food, Rendang

\section{INTRODUCTION}

Indonesia Tourism growth rate in 2015 grew by $7.2 \%$, above-average tourism growth rate in the world, amount $4.4 \%$ and ASEAN growth rate amount only $6 \%$. Indonesia's tourism grow $5.88 \%$ from 2015 until June 2016 based on tourist arrival (Tourism Misintry 2015). The rapid growth in tourism industry gives a significant contribution to food industry, especially traditional Indonesian food industry, as tourists are likely to try and eat traditional foods during their stay in Indonesia.

Food and beverage industry contributed greatly to the national economic growth in Indonesia. Therefore, the Ministry of Industry continues to encourage the development of national food and beverage industry. Based on (Tourism Ministry 2015), the growth of national food and beverage industry reached $8.16 \%$, higher than the growth of non-oil industry amounted to $5.21 \%$. Meanwhile, national economic growth reached $4.71 \%$. Food and beverage industry sector contributed $29.95 \%$ of the non-oil industries GDP, while the non-oil industries contributed $86.4 \%$ of the processing industry or contributed $18.27 \%$ to the National GDP.

Indonesian traditional food lot that goes into the category of the most delicious food in the world. One of them is rendang. Rendang is a spicy flavor of meat dishes which use a mix of various herbs and spices. This cuisine is generated from heated cooking process repeated with coconut milk. Cooking process takes many hours (usually about four hours) to dry and solid black. At room temperature, rendang can last for weeks. This traditional food cooking process can reduce the effectiveness and efficiency Hotel and Restaurant workers. Based on (Sjukriana 2004) for restaurants and hotels, as main food production providers, there are three major perspectives that need to be taken into consideration in order to improve the quality of food production. Firstly, from business point of view, restaurants and hotels will have to focus on the effectiveness, efficiency, hygiene and sanitary in production process, and to improve consistency in quality and taste. Effective and efficient production process is highly recommended especially for restaurants and hotels which provide high capacity of banquet and food service. Fast and simple food process will also give benefits in production and human resource costs. Hygiene and sanitary in production process is strongly related to clean and healthy food products, and it is one of the most vital occupational health and safety issues not only for kitchen work area and staff but also for the entire staff and environment. In addition, consistency in food quality and taste will strengthen customer image and reliability to always use the products.

In customer point of view, they want food which tasty, healthy, clean, and natural food. They also want the food can be served and delivered in a short time, so they are no need wait too long. Recently, people give attention to healthy life style. They consuming natural food that contain no additional additive and preservatives without reduce its taste.

Rendang as traditional food uses a variety of ingredients and produces so many raw material. It takes long time for cooking process. Long cooking process may cause customer 
dissatisfaction, because they need so many time to get they food. Based on these case, researcher has initiated to transform of cooking process to be advance. The transformation will be more effective, clean cooking process, and less food production waste. Dried spice is the transformation of cooking process to be advanced for rendang recipe. It will be solution to reduce cooking process that take long time. By using dried spice for traditional food especially rendang, will give service delivery time very well. Based on the description above, the problem in this study can be formulated as how to analyze the efficiency on food production process by using dried spice? According to the issues, the purpose of this study is to analyze the efficiency on food production process.

\section{METHOD}

Processing and analysis data using qualitative analysis. Qualitative approah use to formulate dried spice for rendang recipe and analyze the efficiency on food production with compare cooking process between conventional and use dried spice. The variable are:

\section{Preparation Time (minute) \\ 2. Cooking Time (minute) \\ 3. Material Cost (IDR) \\ 4. Expired Time (day)}

\section{RESULT AND ANALYSIS}

This research for developing and producing dried spice in cooperation with Hotel Salak the Heritage and PT Sukaraja Pangan Utama. PT Sukaraja Pangan Utama is affiliation with PT Ayam Goreng Fatmawati Indonesia (AGFI) which already exists in Sundanese food industry in many years. Dried spice is instant dried spice that used as a seasoning in cooking process. Pure dried spice have been made by PT Sukaraja Pangan Utama. PT Sukaraja by using stable pressure, low temperature drying process for 24 hours, and intensive quality control which result that content less than $10 \%$ in low water and hygienic product as it is free from bacterial filth and other impurities. Pure spice powder consists of natural ingredients without any filling materials. This research developing formulation dried spice for rendang seasoning by conducting some experiments. The development of dried spice can be divided into four stage: seasoning, formulation, cooking trial, and respondent test and production.

Stage 1: Seasoning Formulation

In this stage, researcher make some formulation for the rendang seasoning. Rendang seasoning made by mixing each pure dried spice accordance with the portions like make rendang seasoning with standard recipe. To make rendang seasoning formulation, needs to convert each ingredients from standard recipe to pure dried spice. After all ingredients pure dried spice are converted then all pure dried spice formulated/combined as a new dried spice for rendang recipe.

\section{Stage 2: Cooking Trial}

The new recipe dried spice for rendang is trialed in a cooking process. Evaluation of cooking process effectiveness and food taste are needed. The purpose of evaluation to reach the most effective of cooking process and the product (rendang) has the same taste with standard quality when cooked by conventional cooking process.

\section{Stage 3: Questionnaire Result}

The food product (rendang) is give to some respondents. Distributing questionnaires to respondents also do to get some inputs and comments related to food taste, texture, aroma, and performance. The questionnaires result from respondent will be evaluation the recipe of dried spice for rendang. Besides, the questionnaire result, product life time also tested. Stage 4 Production Dried spice for rendang recipe produced by finalized all evaluation from cooking trial (stage 2) and questionnaires result (stage 3). It will be a new dried spice for rendang which has same standard quality with conventional cooking process.

\section{Effectiveness of Dried Spice in Food Production}

In this section, will compare which one more effective between cook rendang use dried spice and cook with the conventinal cooking process. The comparison is focused on:

1. The comparison of conventional cooking steps and dried spice process. The variables are preparation time, cooking time, material cost and life time.

2. The comparison the result product. How the product characteristic and its application in relation to hygiene and sanitary of working area.

3. Statistical results from respondent test on food taste, aroma, texture, and performance.

Comparison of Cooking Steps Between Conventional and Spice Powder

Table I and II show all ingredients for conventional and dried spice cooking process, and based on (Hambali et al 2005) Figure 3 illustrates the difference between conventional and dried spice cooking process of rendang. In conventional cooking, peeling, washing, and grounding process of all raw spice materials must be completed, whereas in dried spice cooking, all raw spice materials (15 types of spices, such as red chili, shallot and garlic) have been in powder form, therefore the preparation process can be avoided. This will be a significant benefit for saving preparation time.

TABLE I. INGREDIENTS FOR RENDANG USING CONVENTIONAL

\begin{tabular}{lllll}
\cline { 1 - 2 } \multicolumn{1}{c}{ Material } & \multicolumn{1}{c}{ Net Weight } & \multicolumn{1}{c}{ Gross Weight } & Cost (Idr) \\
\cline { 1 - 1 }$\sim$ Red Chili* & $300 \mathrm{~g}$ & $1 / 2 \mathrm{~kg}$ & 20.000 \\
$\sim$ Shallot* & $60 \mathrm{~g}$ & $1 / 4 \mathrm{~kg}$ & 7.000 \\
$\sim$ Garlic* & $40 \mathrm{~g}$ & $1 / 2 \mathrm{~kg}$ & 7.500 \\
$\sim$ Walnut* & $30 \mathrm{~g}$ & $1 / 4 \mathrm{~kg}$ & 10.000 \\
$\sim$ Cumin* & $2 \mathrm{~g}$ & $1 / 4 \mathrm{~kg}$ & 17.000 \\
$\sim$ Coriander* & $2 \mathrm{~g}$ & $1 / 4 \mathrm{~kg}$ & 5.000 \\
$\sim$ Anister* & $2 \mathrm{~g}$ & $1 / 4 \mathrm{~kg}$ & 3.000 \\
$\sim$ Lemon Grass* & $10 \mathrm{~g}$ & $1 / 4 \mathrm{~kg}$ & 2.500 \\
$\sim$ Galingale* & $10 \mathrm{~g}$ & $1 / 4 \mathrm{~kg}$ & 3.750 \\
$\sim$ Ginger* & $10 \mathrm{~g}$ & $1 / 4 \mathrm{~kg}$ & 5.000 \\
$\sim$ Kaffir & Lime & $10 \mathrm{~g}$ & $1 / 4 \mathrm{~kg}$ & 4.250 \\
Leaves* & & & \\
$\sim$ Salt* & $20 \mathrm{~g}$ & $1 / 4 \mathrm{~kg}$ & 11.250 \\
\hline
\end{tabular}


Table I. Cont.

\begin{tabular}{llll}
\hline$\sim$ Tamarind* & $10 \mathrm{~g}$ & $1 / 4 \mathrm{~kg}$ & 2.250 \\
$\sim$ Cloves* & $0.8 \mathrm{~g}$ & $1 / 4 \mathrm{~kg}$ & 28.750 \\
$\sim \quad$ Turmeric & $6 \mathrm{~g}$ & $1 / 4 \mathrm{~kg}$ & 3.000 \\
Leaves* & & $1 \mathrm{~kg}$ & 120.000 \\
$\sim$ Beef & $1 \mathrm{~kg}$ & $1000 \mathrm{ml}$ & 38.000. \\
$\sim$ Coconut Milk & $1000 \mathrm{ml}$ & $250 \mathrm{ml}$ & $\sim$ \\
$\sim$ Water & $250 \mathrm{ml}$ & IDR 288.250 \\
\hline TOTAL & &
\end{tabular}

TABLE II. INGREDIENTS FOR RENDANG USING DRIED SPICE

\begin{tabular}{lll}
\hline \multicolumn{1}{c}{ Material } & \multicolumn{1}{c}{ Weight } & \multicolumn{1}{c}{ Cost (Idr) } \\
\hline$\sim$ Dried Spice** & $48 \mathrm{~g}$ & 15.000 \\
$\sim$ Beef & $1 \mathrm{Kg}$ & 120.000 \\
$\sim$ Coconut Milk & $400 \mathrm{ml}$ & 38.000 \\
$\sim$ Water & $250 \mathrm{ml}$ & $\sim$ \\
\hline TOTAL IDR 173.000 & & \\
\hline
\end{tabular}

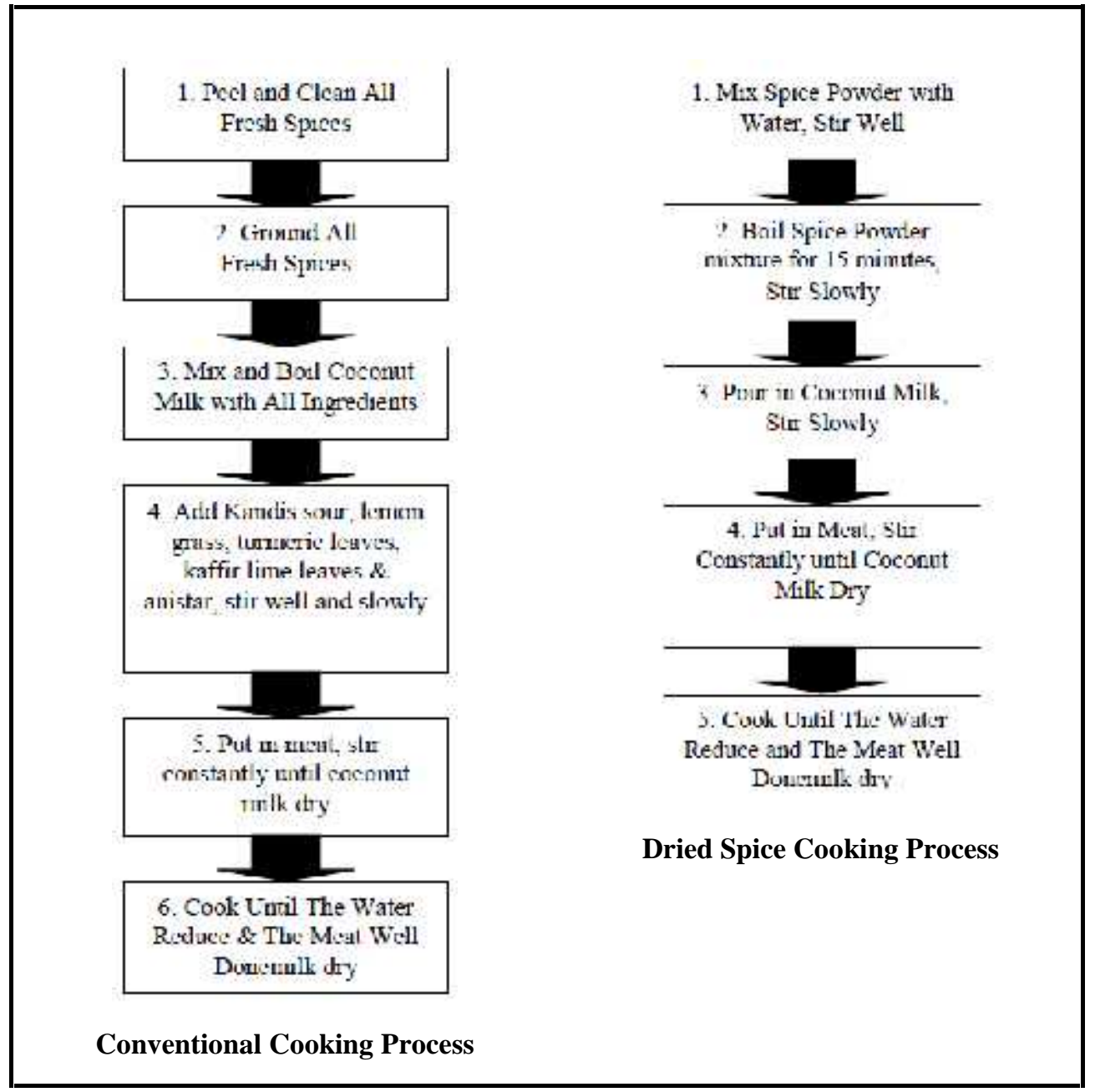

Fig. 1. Comparison on Cooking Process Between Conventional and Dried Spice

Comparison Between Conventional and Spice Powder

\section{Cooking Process}

Analyzing the effectiveness of cooking process using dried spice obtained by compare cooking process between conventional and dried spice. Table III show the result of comparison cooking process between conventional and dried spice. Variable that be measured in effectiveness are preparation time, cooking time, material cost, and expired time. One $\mathrm{kg}$ of beef rendang was produced to calculate the cooking time and material cost.
TABLE III. COMPARISON ON EFFECTIVENESS BETWEEN RENDANG USING CONVENTIONAL AND DRIED SPICE METHODS

\begin{tabular}{llll}
\hline Variable & \multicolumn{2}{l}{ Conventional } & Dried Spice \\
\hline $\begin{array}{l}\text { 1. Cooking Process (min) } \\
\text { Preparation Time }\end{array}$ & 20 & & 10 \\
$\begin{array}{l}\text { Cooking Time } \\
\text { Effectiveness (\%) }\end{array}$ & 150 & $\mathbf{2 3 . 5 3}$ & 120 \\
$\begin{array}{l}\text { 2. Material Cost (IDR) } \\
\text { Effectiveness (\%) }\end{array}$ & 288.250 & & 173.000 \\
$\begin{array}{l}\text { 3. Expired Time (Day) } \\
\text { Effectiveness (\%) }\end{array}$ & 3 & $\mathbf{4 0}$ & 4 \\
\hline
\end{tabular}


The result of effectiveness based on table III, the preparation time for dried spice cooking process faster than conventional cooking process. This is because raw spice material peeling, washing, cleaning and grounding can be avoided. Time saved when use use dried spice in cooking process is 30 minutes. This is because powder form can disperse in coconut milk more easily, whereas in conventional process, the grounded spice materials have to be cooked and waited until all mixed together. Its more effective until $23.53 \%$ when using dried spice as rendang seasoning.

In terms of material cost, it can be seen in Table III that cost for dried spice is IDR 115.250,- lower than using raw materials. Therefore, it is $40 \%$ more cost effective than conventional process. After both products were left in a room temperature, beef rendang from conventional process was spoiled on the third day, while dried spice product was spoiled on the fourth day. This shows that dried spice product can last longer than conventional products. Based on Table I, cost efficiency per month for using dried spice can be analyzed as follow:

TABLE IV. ANALYZING COST EFFICIENCY PER MONTH FOR USING DRIED SPICE

\begin{tabular}{|c|c|c|}
\hline \multicolumn{3}{|c|}{ Assumption } \\
\hline Salary for 2 cooks & 2 x IDR $2,500,000,-/$ month & $\begin{array}{l}\text { IDR 5,000,000,- } \\
\text { /month }\end{array}$ \\
\hline Daily cooking & $1 \mathrm{~kg}$ & - \\
\hline $\begin{array}{l}\text { Cooking process } \\
\text { efficiency }\end{array}$ & $23.53 \% \times$ IDR $5,000,000,-$ & $\begin{array}{l}\text { IDR 1.176.500, } \\
\text { /month }\end{array}$ \\
\hline Material efficiency & IDR $115.250,-$ x 30 days & $\begin{array}{l}\text { IDR 3.457.000,- } \\
\text { /month }\end{array}$ \\
\hline
\end{tabular}

Assumption1:

- Produce Rendang per day : 7.5 kiloos

- 170 minutes produce rendang : 2.5 kiloos

- Standar Time $1: 170$ Minutes

- Time Work per day : 480 Minutes

Man Power $=($ Standar Time $x$ Output $) /$ Working time

Man Power $1=(170 \times 100) / 480=3$ Man Power

Assumption2:

- Produce Rendang per day : 7.5 kiloos

- 130 minutes produce rendang : 2.5 kiloos

- Standar Time $1: 130$ Minutes

- Time Work per day : 480 Minutes

Man Power $=($ Standar Time $x$ Output $) /$ Working time

Man Power $2=(130 \times 100) / 480=2$ Man Power

$\therefore$ MAN POWER EFFICIENCY OF $=33.33 \%$

\section{Effectiveness of Food Production According to Users} Evaluation

Based on questionnaire result in table IV, all users mentioned the preparation and cooking process using dried spice easier than conventional process. For the product result, all users agreed that the food performance was good. The majority of the users said that the taste was good $(86 \%)$, and the aroma was fair $(71 \%)$. In addition, all users stated that using dried spice resulted in hygienic (clean) kitchen area.

TABLE V. PERCENTAGE OF RESPONDENTS ON RENDANG COOKING Process Using DRIED SPICE COMPARED TO CONVENTIONAL Process

\begin{tabular}{llll}
\hline & \multicolumn{3}{c}{ Percentage (\%) } \\
\cline { 2 - 4 } A. Process & Easy & Fair & Difficult \\
\hline Preparation & 100 & - & - \\
Cooking Process & 100 & - & - \\
\hline B. Product Result & Good & Fair & Poor \\
\hline Taste & 86 & 14 & - \\
Aroma & 29 & 71 & - \\
Performance & 100 & - & - \\
\hline C. Working Area & Good & Fair & Poor \\
\hline Hygiene & 100 & - & -
\end{tabular}

Dried spice really help some users especially in hotel, restaurants and catering. Recipe with dried spice is simpler than conventional cooking process. It can reduces preparation of raw material. Besides that, the powder is easy to disperse in food mixes, produce products with consistent standard of taste, no different in aroma, taste, and color of the product from conventional recipe. It can save time and very effective, especially for high volume cooking so make the delivery service time faster and no need extra cook helpers to assist cooking preparation.

Dried spice also make hygiene and sanitary in working area and environmental more maintaned, such as less kitchen waste and usage of raw spice materials, which result in clean cooking process, no peeling and cleaning process, therefore less use of water, no need for excessive raw spice material supply, as all spices have been in powder form, and practical storage, and no need for large storage space. The only space needed is for jars, bottles and containers for the powder. Keeping good storage will make the powder last for months.

\section{Respondent Food Test and Results}

To final result and know people respone on rendang by using dried spice, a food test was conducted. The test will compare how the respondent respon when they try rendang with conventional cooking process and using dried spice. Rendang products were given to 30 (for conventional product) and 30 (dried spice products) respondents. Respondents were asked to fill in the questionnaires on the taste, aroma, texture and performance of both products. 
TABLE VI. PERCEPTION OF RESPONDENTS ON RENDANG PRODUCT COOKED BY USING CONVENTIONAL PROCESS

\begin{tabular}{llll} 
& \multicolumn{3}{c}{ Percentage $\mathbf{( \% )}$} \\
\cline { 2 - 4 } Variable & Good & Fair & Poor \\
\hline Taste & 29 & 64 & 7 \\
Aroma & 10 & 71 & 19 \\
Texture & 14 & 70 & 16 \\
Performance & 17 & 71 & 12 \\
\hline
\end{tabular}

It can be seen in Table VI that from 30 respondents who tasted beef rendang with conventional process, only $29 \%$ of the respondents claimed that the taste is good, and the percentages for aroma, texture and performance were only around 10-17\%.

TABLE VII. PERCEPTION OF RESPONDENTS ON RENDANG PRODUCT COOKED BY USING DRIED SPICE

\begin{tabular}{llll}
\hline & \multicolumn{3}{l}{ Percentage $\mathbf{( \% )}$} \\
\cline { 2 - 4 } Variable & Good & Fair & Poor \\
\hline Taste & 42 & 35 & 23 \\
Aroma & 26 & 56 & 18 \\
Texture & 14 & 62 & 24 \\
Performance & 28 & 56 & 16 \\
\hline
\end{tabular}

Compared with conventional product, it can be seen in Table VII that there was a significant increase of percentage for taste, from $23 \%$ to $42 \%$. For good aroma, the percentage of dried spice product (26\%) is also higher than conventional product $(10 \%)$. For product texture, the percentage is the same $(14 \%)$. For performance, the percentage also increased from $17 \%$ to $28 \%$.

\section{CONCLUSION}

Dried spice can be solution for effectiveness of cooking process. Now no need long time for daily cooking process. Dried spice powder which has been developed in some intensive control and evaluation in the past few years, has shown some excellent benefits to food industry as follows:
1. The most significant time saving. By using dried spice is no requirement for preparation time of raw spice materials. All raw spice materials are substituted by pure powder, therefore the need for peeling, cleaning, washing and grounding process can be avoided.

2. Dried spice provide convenience to some people who work in restaurants, hotel, and catering, because the production of cooking cheaper, faster, and more practical.

3. Give short delivery time to guests.

4. Dried spice can lengthen product life time.

5. Based on food test, the taste, aroma, and performance of dried spice for rendang is increasing.

Dried spice can be a transformation of cooking process to be advance, because it has proven the effectiveness of dried spice without changing the original taste of the product. Besides effectiveness, clean cooking process, which leads to healthier, standard and natural quality and taste of food. This technology can be implemented in all types of food industry.

\section{REFERENCES}

Hambali, Erliza., Fatmawati., Permanik, Ratna. 2005. Membuat Aneka Bumbu Instan Instan Kering. Jakarta (ID): Penebar Swadaya.

[Kemenpar] Tourism Ministry. 2015. The Growth of National Food and Beverage Industry. [Internet]. [accessed on 2016 August, 31]. Available at: http://www.kemenpar.go.id

[Kemenpar] Tourism Ministry. 2015. Tourist Arrival 2015 June 2016. [Internet]. [accessed on 2016 August, 31]. Available at: http://www.kemenpar.go.id

Sjukriana, Juke. 2004. REVOLUTION IN FOOD INDUSTRY : Transform the Paradigm of Conventional to Advanced Cooking Process. Hotel Salak The Heritage. 